\title{
POLA PENDIDIKAN ISLAM DALAM SURAT LUQMAN AYAT 12-19
}

\author{
Sutikno \\ (Kajur PAI FITK IAIN Sunan Ampel)
}

\begin{abstract}
Abstrak
Tulisan ini mengulas pola pendidikan Islam dalam surat Luqman ayat 12-19. Pola pendidikan yang terkandung dalam surat Luqman ayat 12-19 merupakan pola pendidikan yang Islami, pola pendidikan yang berbasis keagamaan. Komponen-komponen pendidikan yang terkandung dalam surat Luqman ayat 12-19 antara lain: pendidik, peserta didik, materi pendidikan, metode pendidikan, dan tujuan pendidikan. Pendidiknya adalah Luqman; peserta didiknya anaknya Luqman; materi pendidikannya berisi aqidah, syari'ah, moral; metode pendidikannya bersifat nasihat; tujuan pendidikannya adalah keimanan, ketaqwaan, dan akhlak yang luhur.
\end{abstract}

Kata Kunci: Pendidikan Islam dan Surat Luqman: 12-19. 


\section{A. Pendahuluan}

Pendidikan merupakan usaha atau tindakan untuk membentuk kepribadian manusia. Pendidikan sangat penting karena ia ikut menentukan corak dan bentuk amal dalam kehidupan manusia, baik pribadi maupun masyarakat. ${ }^{1}$ Di dalam al-Qur'an terdapat banyak ajaran yang berisi prinsip-prinsip berkenaan dengan kegiatan atau usaha pendidikan itu. Seperti kisah Luqman dalam mendidik anaknya. ${ }^{2}$ Cerita itu menggariskan prinsip materi pendidikan yang terdiri dari masalah iman, akhlak ibadah, sosial, dan ilmu pengetahuan. ${ }^{3}$

Al-Qur'an merupakan sumber referensi yang berisi berbagai aspek kehidupan, termasuk juga dalam bidang pendidikan. Sebagai seorang pelajar muslim, sudah seharusnya menjadikan al-Qur'an sebagai dasar dan acuan dalam hal pendidikan. Di dalam al-Qur'an sendiri terdapat banyak sekali ayat yang berkaitan dengan dunia pendidikan. Salah satunya adalah yang terdapat dalam surat luqman ayat 12-19.

Pendidikan Islam diharapkan menghasilkan manusia yang berguna bagi dirinya dan masyarakatnya serta senang dan gemar mengamalkan dan mengembangkan ajaran Islam dalam berhubungan dengan Allah SWT dan sesama manusia, dapat megambil manfaat dari alam semesta ini untuk kepentingan di dunia -masa kini dan di akhirat nanti. $^{4}$

\section{B. Surat Luqman Ayat 12-19}

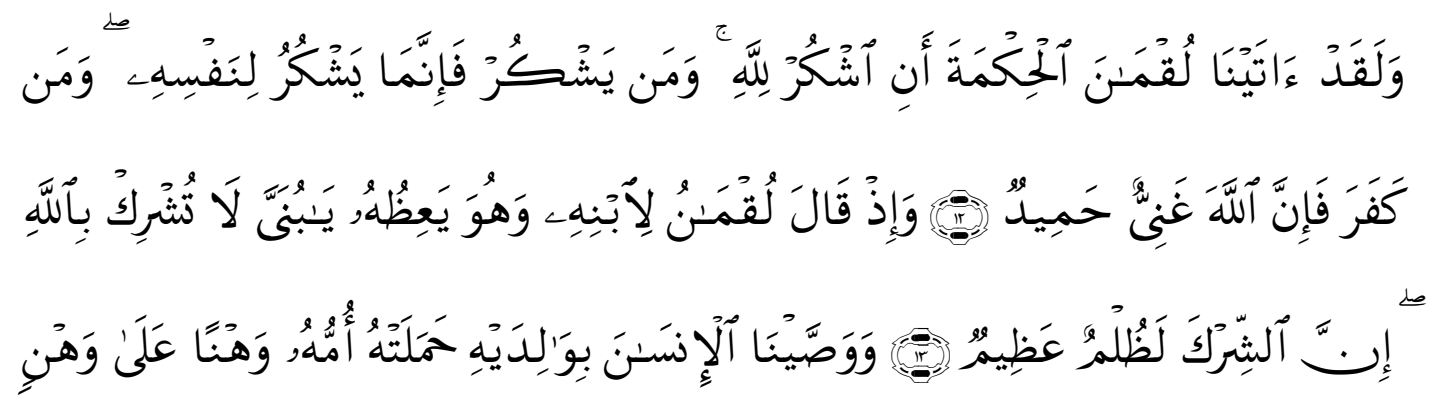

\footnotetext{
${ }^{1}$ Muhaimin, Paradigma Pendidikan Islam dalam Upaya Mengefektifkan Pendidikan Agama Islam di Sekolah, Cet. III (Jakarta: PT. Remaja Rosda Karya, 2004).

${ }^{2}$ QS. Luqman: 12-19

${ }^{3}$ Zakiah Darajat, Ilmu Pendidikan Islam, Cet. ke 8 (Jakarta: Bumi Aksara-Depag RI, 2008), 20.

${ }^{4}$ Zakiah Daradjat, Ilmu Pendidikan Islam, 29. 


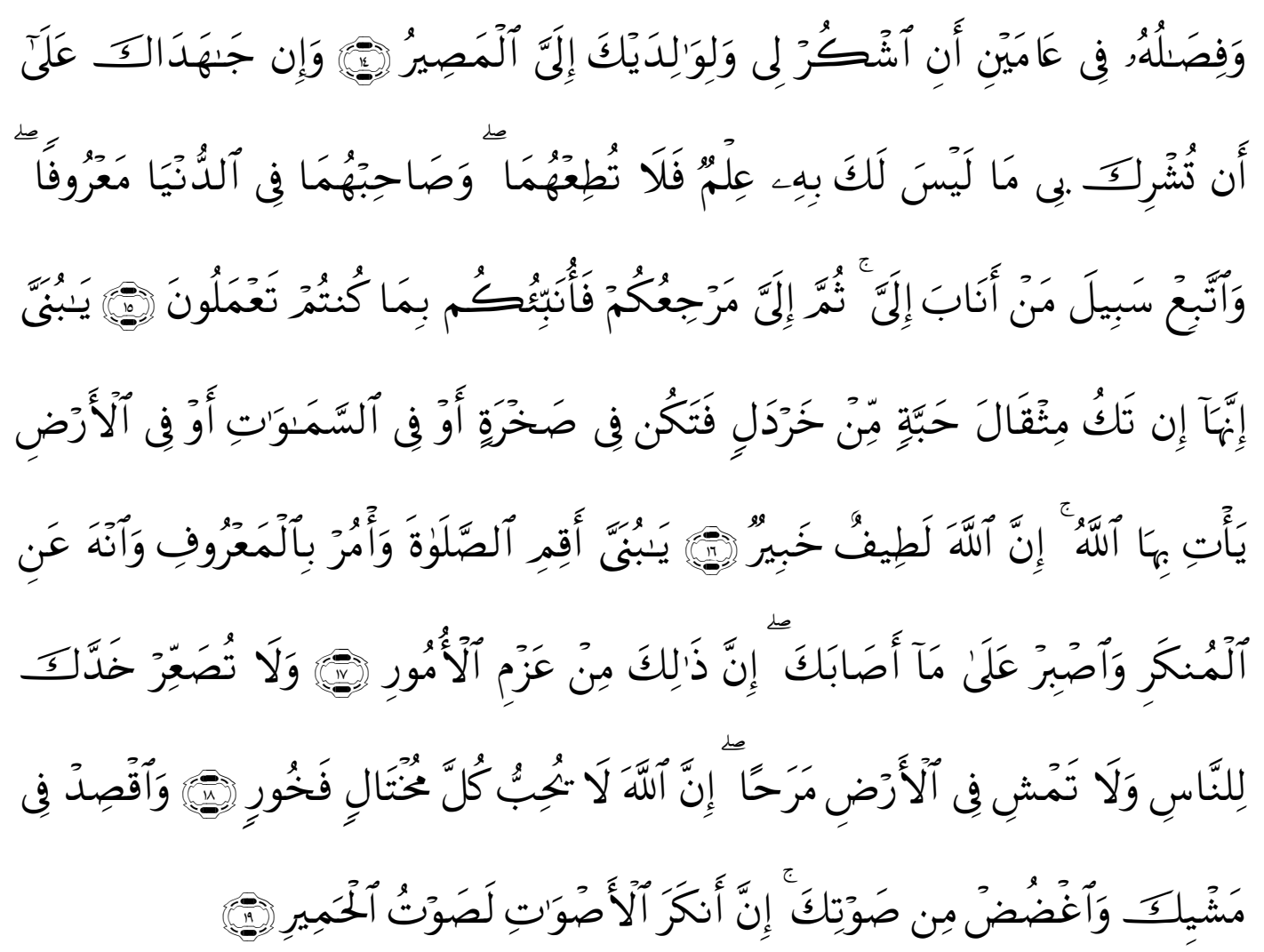

"Dan sesungguhnya telah Kami berikan hikmah kepada Luqman, yaitu: 'Bersyukurlah kepada Allah, Dan barang siapa yang bersyukur (kepada Allah), maka sesungguhnya ia bersyukur untuk dirinya sendiri, dan barang siapa yang tidak bersyukur (kufur), maka sesungguhnya Allah Maha Kaya lagi Maha Terpuji'."

"Dan (ingatlah) ketika Luqman berkata kepada anaknya di waktu ia memberi pelajaran kepadanya: 'Hai anakku, janganlah kamu mempersekutukan Allah, sesungguhnya mempersekutukan (Allah) itu adalah benar-benar kedhaliman yang besar'."

"Dan Kami perintahkan kepada manusia (berbuat baik) kepada dua ibu bapaknya, ibunya telah mengandungnya dalam keadaan lemah yang bertambah-tambah, dan menyapihnya dalam usia dua tahun. Bersyukurlah kepada-Ku dan kepada kedua ibu bapakmu, hanya kepada-Ku kamu kembali."

"Dan jika keduanya memaksamu untuk mempersekutukan-Ku dengan sesuatu yang tidak ada pengetahuanmu tentang itu, maka janganlah kamu mengikuti keduanya, dan pergaulilah keduanya di dunia dengan baik, dan ikutilah jalan orang yang kembali kepada-Ku, kemudian 
hanya kepada-Kulah kembalimu, maka Kuberitakan kepada mu apa yang telah kamu kerjakan."

"(Luqman berkata): 'Hai anakku, sesungguhnya jika ada (sesuatu perbuatan sebesar biji sawi dan berada dalam batu atau langit atau di dalam bumi, niscaya Allah akan mendatangkannya (membalasnya). Sesungguhya Allah Maha Halus lagi Maha Mengetahui'."

"Hai Anakku, dirikanlah shalat dan suruhlah (manusia) mengerjakan yang baik dan cegahlah (mereka) dari perbuatan yang mungkar dan bersabarlah terhadap apa yang menimpa kamu. Sesungguhnya yang demikian itu termasuk hal-hal yang diwajibkan (oleh Allah)."

"Dan janganlah kamu memalingkan muka dari manusia (karena sombong) dan janganlah kamu berjalan di muka bumi dengan angkuh. Sesungguhnya Allah itu tidak menyukai orang-orang yang sombong lagi membangga-banggakan diri."

"Dan sederhanakanlah kamu dalam berjalan dan lunakkanlah suaramu. Sesungguhnya seburuk-buruknya suara ialah suara keledai." (Q.S. Luqman: 12-19). ${ }^{5}$

\section{Pola Pendidikan Islam dalam Surat Luqman Ayat 12 - 19}

Delapan ayat tersebut di atas kental dengan nilai-nilai pendidikan Islam yang harus diterapkan oleh orang tua kepada anak-anaknya sebagaimana Allah telah menjadikan Luqman dan anaknya sebagai contoh proses pendidikan agama dari orang tua kepada anaknya dan contoh tersebut dikemukakan oleh Allah SWT kepada Nabi Muhammad SAW untuk disampaikan kepada segenap umatnya.

\section{Pendidik}

Pendidik dalam surat Luqman ayat 12-19 diwakili oleh Luqman. Luqman yang disebut oleh surat ini adalah seorang tokoh yang diperselisihkan identitasnya. Orang Arab mengenal dua tokoh yang bernama Luqman. Pertama, Luqman Ibn 'Ad. Tokoh ini mereka agungkan karena kewibawaan, kepemimpinan, keilmuan, kefasihan dan kepandaiannya. Dia kerap kali dijadikan sebagai pemisalan dan perumpamaan. Tokoh kedua adalah Luqman al-Hakim yang terkenal dengan kata-kata bijak dan perumpamaan-perumpamaannya. Agaknya

\footnotetext{
${ }^{5}$ Depag RI, Al-Quran dan Terjemahnya (Jakarta: Depag RI, 1971 ), 654-655

Jurnal Pendidikan Agama Islam

Volume 02 Nomor 02 November 2013

Hal 290 - 302
} 
dialah yang dimaksud oleh surat ini. Dalam tafsir Ibnu Katsir bahkan disebutkan nama lengkap Luqman adalah Luqman bin Anqa' bin Sadun menurut kisah yang dikemukakan oleh As-Suhaili. ${ }^{6}$

Al-Baghdadi mengemukakan bahwa Luqman bukan dari kalangan Arab, tetapi seorang 'ajami, yaitu anak Ba'ura dari keturunan Azar (orang tua Nabi Ibrahim), anak saudara perempuan Nabi Ayyub, atau anak bibi nabi Ayyub. Banyak perbedaan pendapat tentang asal-usul Luqman tersebut. Ada yang mengatakan bahwa dia seorang bangsa Negro Sudan, Mesir Hulu atau Habsyi yang warna kulitnya hitam, hidup selama seribu tahun dan berjumpa dengan Nabi Dawud sehingga Nabi Dawud banyak menimba ilmu darinya. Ada yang berpendapat bahwa dia seorang Nabi, dan ada pula yang membantah pendapat itu dengan mengatakan bahwa dia hanyalah seorang ahli hikmah. ${ }^{7}$

Penulis memegang pendapat yang mengatakan bahwa Luqman adalah seorang ahli hikmah, bukan seorang Nabi, karena yang diajarkan kepada anaknya bukanlah wahyu, melainkan hikmah yang telah dianugerahkan Allah dan hal ini sesuai dengan Hadits yang diriwayatkan dari Ibnu Abbas r.a:

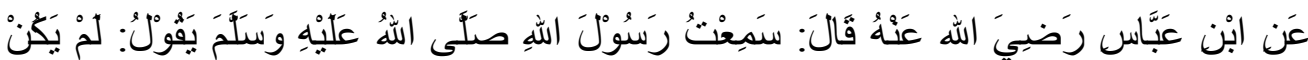

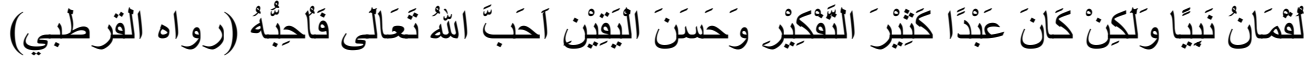
"Dari Ibnu Abbas r.a berkata: Saya mendengar Rasulullah SAW bersabda: Luqman bukanlah seorang Nabi, tapi beliau adalah seorang hamba yang banyak berfikir secara bersih dan penuh keyakinan sehingga dia mencintai Allah dan Allah pun mencintainya, maka dilimpahkan kepadanya Al-Hikmah." (H.R. AlQurthuby).

Luqman adalah seorang ahli hikmah, kata-katanya merupakan pelajaran dan nasihat, diamnya adalah berpikir, dan isyarat-isyaratnya merupakan peringatan. Dia bukan seorang Nabi melainkan seseorang yang bijaksana, yang Allah telah memberikan kebijaksanaan di dalam lisan dan hatinya, dimana dia berbicara dan mengajarkan

${ }^{6}$ Nasib Ar-Rifai, Kemudahan dari Allah, Ringkasan Tafsir Ibnu Katsir, (Jakarta: Gema Insani Press, 1999), 789.

${ }^{7}$ Armai Arief, Reformulasi Pendidikan Islam (Jakarta: CRSD Press, 2005), 182 
kebijaksanaan itu kepada manusia. Dalam al-Qur'an pun diungkapkan bahwa dia dianugerahi berupa "hikmah" oleh Allah SWT.

Sebagai orang tua sekaligus pendidik bagi anaknya, sebagaimana yang tercantum dalam surat Luqman ayat 12-19 bahwasannya Luqman dalam mendidik anak, melakukan tugas sebagai berikut: a. Menanamkan keimanan dalam jiwa anak; b. Mendidik anak agar taat menjalankan agama; c. Mendidik anak agar berbudi pekerti yang mulia.

\section{Peserta Didik}

Secara implisit, peserta didik atau anak didik yang terdapat pada surat Luqman ayat 12-19 adalah putra dari Luqman itu sendiri. Anak merupakan rahmat dari Allah SWT, anak adalah amanah, harus disyukuri, dididik dan dibina agar menjadi orang yang baik, berkepribadian yang kuat dan berakhlaq terpuji. Hal ini merupakan keinginan setiap keluarga terutama orang tua dan semua guru.

Mendidik anak merupakan kewajiban orang tua. Mulai dari kecil haruslah sudah dididik ke arah kebaikan. Dalam keluarga orang tua mempunyai peran yang penting untuk mendidik anaknya. Sebab orang tualah yang dikenal pertama kali oleh anak dengan segala perlakuan yang diterima atau dirasakan dapat menjadi dasar pembentukan pribadinya, karena pada dasarnya manusia waktu dilahirkan dalam keadaan suci tanpa noda dan dosa, ibarat kertas maka orang tualah yang menulisinya. Sebagaimana diterangkan dalam sebuah hadits Nabi yang berbunyi sebagai berikut:

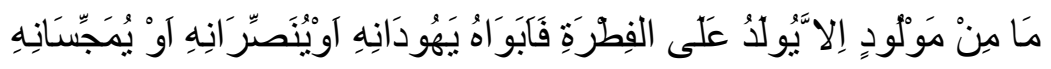

$$
\text { (رو اه مسلم) }
$$

"Tidaklah seorang anak dilahirkan kecuali dalam keadaan suci, maka kedua orang tuanyalah yang menjadikan Yahudi atau Nashrani atau Majusi" (HR. Muslim). ${ }^{8}$

Dalam usaha pendidikan pada anak perlu adanya pengenalan terhadap agama secara ketat terhadap diri anak, agar anak mempunyai

\footnotetext{
${ }^{8}$ Imam Muslim, Shahih Muslim, Juz II (Surabaya: Syarikat 'Alawi, tt.), 458. 
pribadi yang baik yang sesuai dengan agama, yang semua itu dapat dimulai dengan mendidik anak pada waktu masih kecil melalui pendidikan dan pengalaman yang dilaluinya bersama orang tuanya yang berperan sebagai pendidik.

Seorang anak akan menjadi baik ataukah justru menjadi beban dalam masyarakat, sebagian besar merupakan refleksi dari pendidikan yang didapatkannya dalam keluarga. Orang tua dalam keluarga apabila dapat berperan secara maksimal maka akan dapat melahirkan generasi penerus yang lebih baik daripada generasi pada saat ini.

\section{Materi Pendidikan Islam}

\section{a. Keimanan (Aqidah)}

Pendidikan aqidah meliputi peng-Esa-an Allah, tidak menyekutukan-Nya, dan mensyukuri segala nikmat-Nya. Larangan menyekutukan Allah termuat dalam ayat 13 surat Luqman tersebut. Pada ayat ini, Luqman memberikan pendidikan dan pengajaran kepada anaknya berupa aqidah yang mantap, agar tidak menyekutukan Allah. Itulah aqidah tauhid, karena tidak ada Tuhan selain Allah, dan yang selain Allah adalah makhluk.

Ayat ini mendidik manusia bahwa keyakinan pertama dan utama yang perlu ditanamkan dan diresapkan kepada anak (peserta didik) adalah tauhid. Kewajiban ini terpikul di pundak orang tua sebagai pendidik awal dalam pendidikan informal. Demikian juga yang harus dilaksanakan oleh pendidikan formal dan non formal. Tujuannya agar anak (peserta didik) terbebas dari perbudakan materi dan duniawi, sehingga keyakinannya mantap dan aqidahnya kokoh, serta keyakinannya itu perlu diresapkan sedini mungkin di saat anak telah mulai banyak bertanya kepada orang tuanya. ${ }^{9}$

Ayat lainnya yang berbicara mengenai aqidah adalah ayat 16 surat Luqman. Pada ayat ini Luqman kembali kepada aqidah dengan memperkenalkan sifat Allah yang Maha Mengetahui segala sesuatu betapapun kecilnya, walaupun sebesar biji sawi sebagaimana yang dilukiskan dalam ayat tersebut.

\section{b. Ibadah (Syariah)}

${ }^{9}$ Armai Arief, Reformulasi Pendidikan Islam, 188-189. 
Secara umum ibadah diartikan sebagai sesembahan, pengabdian. Ibadah sebenarnya tidak hanya sebatas penyembahan, tetapi juga berhubungan dengan tingkah laku manusia meliputi kehidupan. ${ }^{10}$ Materi ibadah mencakup segala tindakan dalam kehidupan sehari-hari, baik yang berhubungan dengan Allah SWT seperti shalat, maupun dengan sesama manusia. Hubungan kepada Allah SWT dalam bentuk shalat ini dinyatakan oleh ayat 17 surat Luqman.

Pada ayat ini Allah SWT mengabadikan empat bentuk nasihat Luqman untuk penetapan jiwa anaknya, yaitu: 1) Mendirikan shalat, 2) Menyuruh berbuat yang baik (makruf), 3) Mencegah berbuat mungkar, dan 4) Bersabar atas segala musibah. Keempat hal inilah yang diberikan Luqman kepada anaknya dan diharapkan menjadi modal hidup bagi umat Islam sebagaimana yang disampaikan Nabi Muhammad SAW.

Ayat ini mendidik manusia dengan materi pemantapan jiwa dengan mendirikan shalat, diikuti dengan perbuatan makruf, berani menegur yang salah, mencegah yang mungkar, dan bila dalam melakukan itu semua terdapat rintangan, maka diperlukan sifat sabar dan tabah. Sesungguhnya yang demikian itu termasuk yang diwajibkan oleh Allah SWT. Dengan demikian ayat ini memberi indikasi bahwa shalat sebagai peneguh pribadi, amar makruf nahi mungkar dalam berhubungan dengan masyarakat, dan sabar untuk mencapai apa yang dicita-citakan.

\section{c. Akhlaq}

Sejalan dengan usaha membentuk dasar keyakinan/keimanan maka diperlukan juga usaha untuk membentuk akhlaq yang mulia. Berakhlaq yang mulia adalah merupakan modal bagi setiap orang dalam menghadapi pergaulan antar sesamanya. Akhlaq termasuk di antara makna yang terpenting dalam hidup ini. Tingkatnya berada sesudah keimanan/kepercayaan kepada Allah, Malaikatnya, Rasulrasulnya, hari akhir, Qadha dan Qadhar Allah.

${ }^{10}$ Zuhairini, et. al., Filsafat Pendidikan Islam, Cet. Ke-2 (Jakarta: Bumi Aksara, 1995), 158 
Apabila beriman kepada Allah dan beribadat kepada-Nya adalah berkaitan erat dengan hubungan antara hamba dan Tuhannya, maka akhlaq pertama sekali berkaitan dengan hubungan muamalah manusia dengan orang lain, baik secara individu maupun secara kolektif. Tetapi yang perlu diingat adalah akhlaq tidak terbatas pada penyusunan hubungan antara manusia dengan manusia lainnya, tetapi lebih dari itu, juga mengatur hubungan manusia dengan segala yang terdapat dalam wujud kehidupan. ${ }^{11}$

Ajaran mengenai pendidikan akhlaq dijelaskan dalam beberapa ayat, seperti ayat 14 surat Luqman yang sebelumnya juga berbicara mengenai pendidikan keimanan/aqidah. Karena konsekuensi keimanan sebagai keyakinan hati harus diwujudkan dalam sikap dan perbuatan. Tuntunan akhlaq yang mulia mengajarkan beberapa tuntunan yang harus dijalankan seorang manusia kepada Allah SWT, berupa kewajiban, anjuran ataupun larangan. Selain itu, tuntunan akhlaq juga mengajarkan manusia untuk berbakti kepada orang tua, ayah dan ibu yang menjadi perantara kelahirannya di dunia. Selain bersyukur kepada Allah, manusia harus berterima kasih kepada kedua orang tuanya, yang secara lahiriah telah berkorban, bersusah payah, terutama ibu yang mengandung, melahirkan, menyusui dan memelihara dengan penuh kasih sayang. ${ }^{12}$

Ayat lainnya yang menjelaskan ajaran akhlaq juga adalah pada ayat 15 surat Luqman. Ayat ini mendidik manusia agar mendahulukan dan mengutamakan aqidah tauhid dan tidak boleh syirik. Perbedaan aqidah si anak dan orang tua tidak boleh menghalangi pergaulan baik selama hidup di dunia, namun sangat dianjurkan supaya si anak selalu mengajak orang tuanya kepada agama tauhid. Kalau tidak berhasil, maka segala sesuatu diserahkan kepada Allah SWT. Karena kepada-Nyalah akan kembali semua yang ada ini.

${ }^{11}$ Zuhairini, et. al., Filsafat Pendidikan Islam, 156

${ }^{12}$ Darwis Hude, et. al., Cakrawala Ilmu dalam Al-Qur'an (Jakarta: Pustaka Firdaus, 2002), 443 
Ayat selanjutnya yang berbicara tentang akhlaq adalah ayat 16 surat Luqman yang sebelumnya juga berbicara mengenai pendidikan keimanan/aqidah. Ayat ini mendidik manusia agar beramal dengan ikhlas karena Allah SWT, sebab Allah akan membalas semua perbuatan manusia betapapun kecilnya, perbuatan baik dibalas dengan pahala kebaikan, dan perbuatan jahat dibalas dengan kesengsaraan.

Oleh sebab itu jika berbuat baik janganlah semata-mata ingin diketahui oleh manusia. Tetapi berharaplah penghargaan dari Allah SWT semata yang dapat menilai dan menghargainya. Ayat ini sangat penting untuk memperkuat hubungan batin insan dengan Tuhannya, pengobat jerih payah atas amal usaha yang kadangkadang tidak ada penghargaan dari manusia. Oleh sebab itu, berdasarkan ayat ini, mendorong manusia untuk bekerja keras dan beramal dengan ikhlas karena Allah semata. ${ }^{13}$

Ayat selanjutnya yang menggariskan prinsip-prinsip akhlaq adalah ayat 18 surat Luqman. Ayat ini mendidik manusia dalam pergaulan dengan masyarakat dengan etika yang baik, berbudi pekerti, sopan santun, dan akhlaq yang tinggi, yaitu tidak boleh sombong, kalau sedang bercakap berhadapan dengan orang lain, hendaklah berhadapan muka, sebab sebagai pertanda berhadapan hati. Sebaliknya tidak boleh memalingkan muka, karena dengan demikian akan tersinggung perasaan lawan bicara, dan merasa dirinya tidak dihargai.

Ajaran sama tentang akhlaq juga dimuat dalam ayat 19 surat Luqman. Ayat ini sebagai kelanjutan dari ayat 18 yang mendidik manusia bertingkah laku sopan di tengah masyarakat, yaitu sederhana dalam berjalan, jangan terlalu cepat, tergopoh-gopoh, terburu-buru, akan cepat lelahnya, dan jangan pula terlalu lambat, sebab akan membawa kemalasan dan membuang waktu di jalan, melainkan hendaklah bersikap sederhana. Demikian juga bila berbicara, jangan dengan suara keras jika tidak ada kepentingan tertentu, jangan berteriak dan menghardik-hardik, menyerupai suara keledai. Oleh sebab itu, ayat ini juga mendidik manusia agar

${ }^{13}$ Armai Arief, Reformulasi Pendidikan Islam, 196-197

Jurnal Pendidikan Agama Islam

Volume 02 Nomor 02 November 2013

Hal 296 - 302 
bersikap halus, bersuara lemah lembut, sehingga bunyi suara itu pun menarik orang untuk memperhatikan apa yang dikatakan, sehingga timbul rasa simpati dari si pendengar.

\section{Metode Pendidikan Islam}

Dalam surat Luqman ayat 12-19 metode yang digunakan dalam pendidikan Islam adalah metode mauidhah. Mauidhah berarti nasihat, kata tersebut sejalan dengan makna kata "wa'adha", "ya'idhu", wa'dhan", "wa'idhatan", dan "wa mau'idhatan" yang berarti memberi nasihat. Al-Qur'an menggunakan kalimat-kalimat yang menyentuh hati untuk mengarahkan manusia kepada ide yang dikehendakinya. Inilah kemudian yang dikenal dengan nasihat dan ayat-ayat al-Qur'an kerap kali dengan nasihat. Allah menjelaskan:

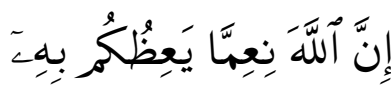

"...Sesungguhnya Allah memberi pengajaran yang sebaik-baiknya kepadamu." (Q.S. An-Nisa: 58).

Menurut Abdurrahman An-Nahlawi "mauidhah" adalah sesuatu yang dapat mengingatkan seseorang akan apa yang dapat melembutkan kalbunya, yang menyangkut perihal pahala atau siksa, yang disajikan dalam bentuk nasihat yang menyentuh, sehingga menimbulkan kesadaran pada dirinya. Istilah mauidhah disebut juga sebagai al-wa'dhu, yakni pemberian nasihat dan peringatan akan kebaikan dan kebenaran dengan cara menyentuh kalbu dan menggugah untuk diamalkannya. ${ }^{14}$

Dengan demikian mauidhah itu adalah sesuatu yang di dalamnya mengandung unsur nasihat dan peringatan yang dapat menimbulkan kesadaran pada diri orang yang diberi nasihat. Karena itu mauidhah harus disajikan dengan cara-cara yang menyentuh kalbu agar dapat menggugah perasaan orang yang diberi nasihat dan mengarahkannya kepada isi nasihat yang diberikan, tanpa ada tujuan menggurui, supaya dengan kesadaran dirinya menerima dan mengamalkan isi nasihat itu.

${ }^{14}$ Syahidin, Metode Pendidikan Qur'ani, Teori dan Aplikasi, Cet. Ke-2 (Jakarta: Misaka Galiza, 1999), 104. 
Syahidin dalam bukunya menyimpulkan bahwa yang dimaksud metode mauidhah ialah suatu cara penyampaian materi pelajaran melalui tutur kata yang berisi nasihat-nasihat dan peringatan tentang baik buruknya sesuatu. ${ }^{15}$ Memberi nasihat merupakan salah satu metode penting dalam pendidikan Islam. Dengan metode ini pendidik dapat menanamkan pengaruh yang baik ke dalam jiwa apabila digunakan dengan cara yang mengetuk relung jiwa melalui pintunya yang tepat.

Dengan metode nasihat, pendidik mempunyai kesempatan yang luas untuk mengarahkan peserta didik kepada berbagai kebaikan, kemaslahatan serta kemajuan masyarakat dan umat. Cara yang dimaksud ialah hendaknya nasihat lahir dari hati yang tulus. Artinya, pendidik berusaha menimbulkan kesan bagi peserta didiknya bahwa dia adalah orang yang mempunyai niat baik dan sangat peduli terhadap kebaikan peserta didik. Hal inilah yang membuat nasihat mendapat penerimaan yang baik dari orang yang diberi nasihat. ${ }^{16}$

Dalam menguraikan metode nasihat ini, guru perlu mempertimbangkan empat (4) hal, yaitu: a. Faktor badaniah guru, maksudnya penampilan fisik guru harus mencerminkan isi nasihat itu, seperti pakaiannya, mimik mukanya, tutur kata dan intonasi suara; $b$. Faktor historisitas murid, artinya guru harus memahami latar belakang kehidupan murid secara umum, dari latar belakang sosial dimana murid itu lahir dan dibesarkan, petani, pedagang, atau pegawai misalnya; c. Faktor dunia murid, maksudnya nasihat itu harus disesuaikan dengan tingkat usia dan pemahaman murid. Menasihati anak usia SD berbeda dengan menasihati murid usia SMA; d. Faktor komunikasi, maksudnya ungkapan dan tutur kata guru harus dapat dipahami oleh murid. Di sini guru harus menggunakan bahasa yang biasa digunakan oleh murid. ${ }^{17}$

Agar supaya nasihat menjadi efektif, maka pemberi nasihat harus memperhatikan syarat-syaratnya. Berikut ini adalah syaratsyarat supaya nasihat itu menjadi efektif:

${ }^{15}$ Syahidin, Metode Pendidikan Qur'ani, 104.

${ }^{16}$ Hery Noer Aly, Ilmu Pendidikan Islam (Jakarta: Logos, 1999), 191

${ }^{17}$ Hery Noer Aly, Ilmu Pendidikan Islam, 104

Jurnal Pendidikan Agama Islam

Volume 02 Nomor 02 November 2013

Hal 298 - 302 
a. Si pemberi nasihat harus terlebih dahulu mengamalkan apa yang dinasihatkannya. Kata-katanya harus menjadi cermin perbuatannya. Kalau apa yang dikatakan dengan apa yang dilakukan tidak sejalan, maka nanti tidak akan ada yang mendengar. Imam Ali kw mengatakan: "Sesungguhnya seorang alim jika tidak mengamalkan ilmunya, maka nasihatnya akan meleset dari hatinya seperti hujan yang meleset dari tempat yang licin". Dia juga mengatakan: "Nasihat tidak akan dikeluarkan oleh telinga dan yang bermanfaat adalah nasihat yang tidak dikatakan oleh mulut tapi dijelmakan dalam perbuatan". Oleh karena itu efektifitas nasihat tergantung pada kredibilitas pemberi nasihat.

b. Berikan nasihat secara khusus, jangan di depan orang ramai, supaya orang yang dinasihati tidak merasa malu untuk menerima kenyataan dirinya. Jangan mempermalukan anak-anak remaja yang umumnya masih sangat peka dan emosional, kecuali kalau isi nasihat itu adalah hal-hal yang umum. Imam Ali kw mengatakan: "Memberi nasihat di depan orang banyak sama saja dengan mengejeknya".

c. Sampaikan nasihat secara singkat karena jika terlalu bertele-tele akan membosankan.

d. Nasihat itu harus jelas dan disesuaikan dengan kebutuhan psikologis pendengarnya.

e. Berikan nasihat secara bertahap, jelaskan terlebih dahulu hal-hal prinsip sebelum hal-hal yang tidak prinsip, kalau yang dinasihati mau menerima hal-hal yang prinsipil yang disampaikan, maka barulah melangkah ke hal-hal yang lain. Kalau tidak demikian, maka hasilnya akan negatif. Seperti memberi nasehat seorang wanita yang imannya masih lemah dan tidak memakai jilbab, maka nasihat pertama adalah tentang memperkuat keyakinan sebelum menyuruhnya untuk memakai jilbab.

f. Berikan nasihat dengan penuh perhatian dan rasa cinta, jangan menggurui atau memarahinya. ${ }^{18}$

${ }^{18}$ Ibrahim Amini, Agar tak salah Mendidik Anak, Penerjemah, Ahamad Subandi \& Salman Fadlullah, (Jakarta: Al-Huda, 2006), 327-328

Jurnal Pendidikan Agama Islam Volume 02 Nomor 02 November 2013 
Sebagai salah satu metode, mauidhah mempunyai beberapa bentuk antara lain sebagai berikut:

a. Nasihat Langsung

Secara etimilogis "nasihat" berasal dari kata "nashaha" (نصح) yang mengandung arti "keterlepasan dari segala kotoran dan tipuan". Secara lughawi kata "nasihat" itu harus terhindar dari kata yang kotor, tipuan, dan dusta, dan hal ini sejalan dengan makna syar'i dimana nasihat itu menyangkut kebenaran dan kebajikan yang harus jauh dari sifat tercela seperti tipuan dan dosa. ${ }^{19}$ Seperti ungkapan (رَجُلْ نَاصِحُ الجَيَبِ) Rajulun nashih al-jaib yang berarti orang yang tidak memiliki sifat menipu, dan al-nashih (النَّاصيح) berarti madu murni. Atas dasar pengertian ini, kata Abdurrahman al-Nahlawi, indikasi nasihat yang tulus ialah orang yang memberi nasihat tidak berorientasi kepada kepentingan material pribadi.

Pendidik yang memberi nasihat secara tulus harus menghindarkan diri dari segala bentuk sifat riya dan pamrih agar tidak menodai keikhlasannya sehingga kewibawaan edukatif dan pengaruhnya terhadap jiwa peserta didik menjadi hilang. ${ }^{20}$

Secara terminologis, nasihat merupakan sajian gambaran tentang kebenaran dan kebajikan, dengan maksud mengajak orang yang dinasihati untuk menjauhkan diri dari bahaya dan membimbingnya ke jalan yang bahagia dan berfaidah baginya. Metode mauidhah berbentuk nasihat ini memiliki keistimewaan, antara lain dapat membuka jalan untuk mempengaruhi perasaan dan pikiran yang mengarah kepada kebajikan. ${ }^{21}$

b. Tadzkir

Bentuk lain metode mauidhah ialah tadzkir (peringatan) yakni mengingatkan berbagai makna dan kesan yang dapat membangkitkan perasaan dan emosi untuk segera beramal saleh, dekat dengan Allah, serta melaksanakan segala perintah-Nya. Bentuk tadzkir ini mempunyai beberapa dimensi, antara lain,

${ }^{19}$ Syahidin, Metode Pendidikan Qur'ani, 111

${ }^{20}$ Hery Noer Aly, Ilmu Pendidikan Islam, 192

${ }^{21}$ Syahidin, Metode Pendidikan Qur'ani, 112

Jurnal Pendidikan Agama Islam

Volume 02 Nomor 02 November 2013

Hal $300-302$ 
tadzkir akan kematian, tadzkir akan musibah, tadzkir mengenai penghisaban, dan sebagainya.

Penggunaan metode mauidhah dalam pengajaran melalui bentuk ini dimaksudkan untuk dijadikan pendorong yang kuat dalam memunculkan rasa risih dalam memandang perbuatan yang seharusnya. Dengan kata lain, metode mauidhah bentuk tadzkir ini membimbing fitrah-potensi baik agar tetap berada pada kebaikan dan berkembang menuju kesempurnaan, serta menghadang potensi buruk agar tidak berkembang. Agar metode ini benar-benar menggugah kalbu dan pikiran siswa, sebaiknya dilakukan dalam situasi yang tepat. ${ }^{22}$

\section{Tujuan Pendidikan Islam}

Berdasarkan materi pendidikan yang terdapat pada surat Luqman ayat 12-19 dapat dirumuskan, bahwa tujuan pendidikan Islam adalah: a. Mencetak manusia yang beriman; b. Mencetak manusia yang bertaqwa; c. Mencetak manusia yang berakhlakul karimah. Apabila melihat penjelasan tersebut, maka tujuan pendidikan Islam yang ingin dicapai bersifat menyeluruh, yakni mencakup kesempurnaan hidup manusia dalam arti yang seluas-luasnya.

\section{Kesimpulan}

Pola pendidikan yang terkandung dalam surat Luqman ayat 12-19 merupakan pola pendidikan yang Islami, pola pendidikan yang berbasis keagamaan. Indikatornya, muatan materinya kental dengan materi keimanan dan akhlaq yang mulia. Tujuan pendidikannya mengarah pada pembentukan kepribadian manusia yang beriman dan berakhlak mulia.

Komponen-komponen pendidikan yang terkandung dalam surat Luqman ayat 12-19 antara lain: pendidik, peserta didik, materi pendidikan, metode pendidikan, dan tujuan pendidikan. Pendidiknya adalah Luqman; peserta didiknya anaknya Luqman; materi pendidikannya berisi aqidah, syari'ah, moral; metode pendidikannya bersifat nasihat; tujuan pendidikannya adalah keimanan, ketaqwaan, dan akhlak yang luhur.

${ }^{22}$ Syahidin, Metode Pendidikan Qur'ani, 113 


\section{DAFTAR PUSTAKA}

Armai Arief, Reformulasi Pendidikan Islam (Jakarta: CRSD Press, 2005)

Depag RI, Al-Quran dan Terjemahnya (Jakarta: Depag RI, 1971).

Darwis Hude, et. al., Cakrawala Ilmu dalam Al-Qur'an (Jakarta: Pustaka Firdaus, 2002).

Hery Noer Aly, Ilmu Pendidikan Islam (Jakarta: Logos, 1999).

Imam Muslim, Shahih Muslim, Juz II (Surabaya: Syarikat 'Alawi, tt.).

Ibrahim Amini, Agar tak salah Mendidik Anak, Penerjemah, Ahamad Subandi \& Salman Fadlullah, (Jakarta: Al-Huda, 2006).

Muhaimin, Paradigma Pendidikan Islam dalam Upaya Mengefektifkan Pendidikan Agama Islam di Sekolah, Cet. III (Jakarta: PT. Remaja Rosda Karya, 2004).

Nasib Ar-Rifai, Kemudahan dari Allah, Ringkasan Tafsir Ibnu Katsir, (Jakarta: Gema Insani Press, 1999).

Syahidin, Metode Pendidikan Qur'ani, Teori dan Aplikasi, Cet. Ke-2 (Jakarta: Misaka Galiza, 1999).

Zuhairini, et. al., Filsafat Pendidikan Islam, Cet. Ke-2 (Jakarta: Bumi Aksara, 1995).

Zakiah Darajat, Ilmu Pendidikan Islam, Cet. ke 8 (Jakarta: Bumi AksaraDepag RI, 2008). 